\title{
Effects of vitamin D binding protein phenotypes and vitamin D supplementation on serum total 25(OH)D and directly measured free 25(OH)D
}

\author{
Stina T Sollid ${ }^{1,2}$, Moira Y S Hutchinson ${ }^{1,3}$, Vivian Berg ${ }^{4}$, Ole M Fuskevåg ${ }^{4}$, \\ Yngve Figenschau ${ }^{4,5}$, Per $M$ Thorsby ${ }^{6}$ and Rolf Jorde ${ }^{1,2}$ \\ ${ }^{1}$ Tromsø Endocrine Research Group, Department of Clinical Medicine, UiT The Arctic University of Norway, \\ Tromsø, Norway, ${ }^{2}$ Division of Internal Medicine, University Hospital of North Norway, 9038 Tromsø, Norway, \\ ${ }^{3}$ Division of Head and Motion, Department of Rheumatology, Nordland Hospital, Bodø, Norway, ${ }^{4}$ Division of \\ Diagnostic Services, University Hospital of North Norway, Tromsø, Norway, ${ }^{5}$ Department of Medical Biology, \\ UiT The Arctic University of Norway, Tromsø, Norway and ${ }^{6}$ Hormone Laboratory, Department of Medical \\ Biochemistry, Oslo University Hospital, Oslo, Norway
}

\author{
Correspondence \\ should be addressed \\ to S T Sollid \\ Email \\ stina.therese.sollid@unn.no
}

\begin{abstract}
Objective: To determine the relationship between serum total 25-hydroxyvitamin $\mathrm{D}(25(\mathrm{OH}) \mathrm{D})$, directly measured free $25(\mathrm{OH})$ $\mathrm{D}$ and calculated free 25(OH)D with regard to vitamin D-binding protein (DBP) phenotypes, sex, BMI, age and season, and their interrelationship to vitamin $\mathrm{D}$ supplementation.

Design, patients and interventions: A randomized controlled trial with $20000 \mathrm{IU}$ of vitamin $\mathrm{D}_{3}$ per week or placebo for 12 months was designed. A total of 472 subjects, 236 in each of the intervention groups, were included in the analyses. Main outcome measures: Baseline serum concentrations and increases in serum total 25(OH)D, directly measured free 25(OH)D, calculated free 25(OH)D and DBP.

Results: Serum total 25(OH)D and DBP concentrations were significantly lower in subjects with the phenotype Gc2/Gc2 compared to phenotypes with the Gc1S allele, and lower in males compared to females. When using directly measured free 25(OH)D, the differences related to DBP phenotypes and sexes were clearly diminished. All calculated free 25(OH)D concentrations were overestimated compared to the directly measured free 25(OH)D. Serum parathyroid hormone showed an inverse correlation with all vitamin $D$ parameters analyzed. The increases after 12 months of vitamin $D$ supplementation were not significantly different for any of the vitamin D parameters regardless of DBP phenotype, sex or age.

Supplementation with vitamin D did not affect serum DBP.

Conclusion: Direct measurements of free 25(OH)D reduce the differences seen in total 25(OH)D between DBP phenotype groups and sexes, probably caused by differences in DBP concentrations. With conditions affecting serum DBP concentrations, direct measurements of free 25(OH)D should be considered.
\end{abstract}

\section{Introduction}

Total 25-hydroxyvitamin D $(25(\mathrm{OH}) \mathrm{D})$ is the metabolite used to evaluate a person's vitamin D status. In the circulation close to $90 \%$ of total $25(\mathrm{OH}) \mathrm{D}$ are bound to vitamin D-binding protein (DBP) with high affinity, about $10 \%$ are more loosely bound to albumin and $<0.1 \%$ are in an unbound, or free, form (1). For the calculation of free $25(\mathrm{OH}) \mathrm{D}$ one therefore needs to know serum total $25(\mathrm{OH}) \mathrm{D}$ concentrations as well as serum DBP and albumin concentrations (2). Recently it has also been possible to measure free $25(\mathrm{OH}) \mathrm{D}$ directly using a
(C) 2016 The authors Published by Bioscientifica Ltd.

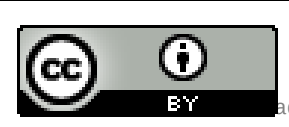

This work is licensed under a Creative Commons Attribution 3.0 Unported License. 
commercially available kit. According to the 'free hormone hypothesis' it is the unbound hormone that is the biologically active; for $25(\mathrm{OH}) \mathrm{D}$ this may also include the fraction bound to albumin that together with the unbound form have been classified as 'bio-available' 25(OH)D (3).

DBP is synthesized by the liver, a process that is stimulated by estrogen (4). Some conditions, such as cirrhosis due to affected synthesis (5) and nephritic syndrome due to protein loss (4) are associated with low DBP concentrations, while pregnancy (6) and estrogen therapy (7) are both known to cause higher DBP concentrations. More than 120 genetic variations of DBP exist; however, for practical purposes the three major polymorphic alleles of DBP in humans, GC1F, GC1S and GC2, yielding six allelic combinations and corresponding phenotypes, are the relevant ones (8). These genetic factors have been showed to explain almost $80 \%$ of the variations in serum DBP concentrations, which show great differences between ethnic groups (9). Thus, in Europeans the Gc1S allele is most frequently seen, whereas in Africans GC1F is the most common allele (4).

In spite of lower serum total $25(\mathrm{OH}) \mathrm{D}$ concentrations African Americans have better bone health and less fractures than European Americans (10). However, Powe et al. (9) have shown that the known differences in serum total 25(OH)D between African and European Americans equalizes when evaluating calculated free or bio-available $25(\mathrm{OH}) \mathrm{D}$ concentrations, and differences in serum total $25(\mathrm{OH}) \mathrm{D}$ may therefore not reflect differences in biological activity. Recently this finding in African and European Americans was confirmed by Aloia et al. (11) using directly measured free serum 25(OH)D. Accordingly, other differences in serum total $25(\mathrm{OH}) \mathrm{D}$, like those between DBP phenotypes, sexes, age groups, BMI categories, as well as seasons, may diminish or disappear when evaluating free $25(\mathrm{OH}) \mathrm{D}$ concentrations. On the other hand, relations with presumed vitamin D related effects, like parathyroid hormone (PTH) secretion, might increase.

Furthermore, there are conflicting reports on the DBP response to vitamin $\mathrm{D}$ supplementation $(12,13)$. If a response exists, that would affect not only the total $25(\mathrm{OH}) \mathrm{D}$, but to an even greater degree the free $25(\mathrm{OH}) \mathrm{D}$ concentrations. We have recently performed a large randomized controlled trial (RCT) with high dose vitamin D supplementation where we have genotyped for DBP polymorphisms, have calculated and directly measured concentrations of free serum $25(\mathrm{OH}) \mathrm{D}$, and therefore had the opportunity to address the above questions.

\section{Subjects and methods}

\section{Overall design}

The data in the present study (baseline and 12 months) were obtained from an RCT where vitamin D vs placebo was given to subjects with prediabetes for 5 years with prevention of diabetes as primary endpoint. Included in the analysis are those with complete datasets for serum albumin, serum total $25(\mathrm{OH}) \mathrm{D}$, serum directly measured free $25(\mathrm{OH}) \mathrm{D}$ and serum DBP.

\section{Study population}

Methods regarding the conduct of the RCT have been published in detail previously (14). Briefly, inclusion criteria were 21-80 years of age and impaired fasting glucose (IFG) and/or impaired glucose tolerance (IGT). Exclusion criteria were primary hyperparathyroidism, sarcoidosis or other granulomatous disorders, urolithiasis, cancer during the last 5 years, reduced kidney function, or unstable angina pectoris, acute myocardial infarction or stroke the last year. Fertile women had to use contraception, could not be pregnant, and could not be lactating. Study participants were allowed to take vitamin D supplements of maximum $400 \mathrm{IU} /$ day. At baseline 511 subjects received study medication, 256 subjects were given $20000 \mathrm{IU}$ of vitamin $\mathrm{D}_{3}$ per week and 255 placebo. Four hundred eighty-four, 242 in each group, completed the 1-year visit.

\section{Measurements}

Height and weight were measured wearing light clothing and no shoes. BMI was calculated as weight $(\mathrm{kg})$ divided by squared height $\left(\mathrm{m}^{2}\right)$. Serum calcium, serum PTH and $\mathrm{HbA}_{1 \mathrm{c}}$ were measured as previously described (15). Serum total 25(OH)D was measured by an in-house LC-MS/MS, the limit of detection (LoD) was $<4 \mathrm{mmol} / \mathrm{l}$, and the between day coefficient of variation (CV) $<9 \%$ (16). Serum albumin was measured by a colorimetric method (bromocresol green) using an automated analyzer, Cobas 8000 (c702, Roche Diagnostics). Serum DBP was measured by using an in house competitive RIA with a polyclonal antibody according to Kauppinen-Mäkelin et al. (17) at the Hormone Laboratory, Oslo University Hospital. Direct measurement of serum free 25(OH)D was done using a competitive ELISA kits from Diasource Diagnostics based on patented MAB developed by Future Diagnostics (http://www.vitamin-d-diagnostics.com/ Vitamin-D/Free-25OH-Vitamin-D/Free-25OH-Vitamin-DELISA-96-tests-RUO), the range was $0.2-87.4 \mathrm{pmol} / \mathrm{l}$, the LoD was $7.0 \mathrm{pmol} / 1$ and the precision was $<10 \%$. 


\section{Genotyping and calculations of free and bio-available 25(OH)D}

Genotyping was performed by KBiosciences (http://www. lgcgenomics.com/genotyping/) with a competitive allelespecific PCR (KASPar) assay. Based on genotyping for two single-nucleotide polymorphisms (SNPs) in the DBP gene (rs7041 and rs4588), the six phenotypes were identified (Supplementary Tables 1 and 2, see section on supplementary data given at the end of this article). For serum $25(\mathrm{OH}) \mathrm{D}$ the binding coefficient for albumin is $6 \times 10^{5} / \mathrm{M}$ and the binding coefficient for DBP is $7 \times 10^{8} / \mathrm{M}(2)$. Free- and bio-available serum $25(\mathrm{OH}) \mathrm{D}$ concentrations were calculated using serum total $25(\mathrm{OH}) \mathrm{D}, \mathrm{DBP}$ and albumin concentrations using a free testosterone equation (18) adapted for calculating free 25(OH)D (19) (Supplementary material).

\section{Statistical analysis}

Normal distribution was evaluated by visual inspection of histograms and by skewness and kurtosis. Normally distributed data are presented as mean \pm s.D., PTH being the only non-normally distributed variable is presented as median (2.5th and 97.5th percentiles). Level of significance was set at $P<0.05$ (two-tailed). Independent samples $t$-test was used to compare the vitamin-D and placebo groups, whereas paired samples $t$-tests were used to compare serum calculated free $25(\mathrm{OH}) \mathrm{D}$ and directly measured free $25(\mathrm{OH}) \mathrm{D}$. For sex $\chi^{2}$ test and for age and BMI one-way ANOVA were used to determine differences in distribution between DBP phenotype groups, BMI groups and age groups. A general linear model was used to examine the DBP phenotype - vitamin D parameters associations with sex, BMI, age and season as covariates. The Bonferroni procedure was used for post-hoc analysis. Independent sample $t$-tests were used to evaluate differences between sex and season, whereas linear trend analyses were used across BMI groups and age groups. Univariate correlations were assessed with Pearson correlation coefficient (PTH was log transformed). IBM SPSS Statistics version 22 was used for all statistical analyses.

\section{Ethics}

The study was approved by the Norwegian Medicines Agency and by the Regional Committee for Medical Research Ethics. The trial is registered at ClinicalTrials.gov (NCT00685594).

\section{Results}

\section{Participant characteristics}

Complete data sets were available in 472 subjects, 236 in each of the intervention groups. Baseline values are presented in Table 1 . The directly measured free $25(\mathrm{OH}) \mathrm{D}$ concentrations were lower than the calculated free 25(OH)D (Table 1). There were no significant differences between the vitamin $\mathrm{D}$ and placebo groups.

\section{Serum total 25(OH)D, calculated free 25(OH)D, calculated bio-available 25(OH)D, directly measured free 25(OH)D and DBP in relation to DBP phenotypes at baseline}

As expected, Gc1S was by far the most abundant allele. There were no significant differences between the DBP phenotypes regarding sex, BMI, age or albumin (Table 2).

Table 1 Baseline characteristics of all subjects and according to randomization status.

\begin{tabular}{|c|c|c|c|}
\hline & \multirow[b]{2}{*}{ All subjects } & \multicolumn{2}{|c|}{ Randomization status } \\
\hline & & Vitamin D & Placebo \\
\hline Number of subjects & 472 & 236 & 236 \\
\hline Male/female & $293 / 179$ & $150 / 86$ & $143 / 93$ \\
\hline $\mathrm{BMI}\left(\mathrm{kg} / \mathrm{m}^{2}\right)$ & $29.9 \pm 4.3$ & $30.1 \pm 4.2$ & $29.8 \pm 4.4$ \\
\hline Age (years) & $62.0 \pm 8.7$ & $62.0 \pm 8.2$ & $62.0 \pm 9.1$ \\
\hline $\mathrm{HbA}_{1 \mathrm{c}}(\%)$ & $6.0 \pm 0.3$ & $6.0 \pm 0.3$ & $6.0 \pm 0.3$ \\
\hline Serum calcium (mmol/l) & $2.31 \pm 0.08$ & $2.31 \pm 0.07$ & $2.31 \pm 0.08$ \\
\hline Serum PTH (pmol/l) & $5.3(5.5,5.9)$ & $5.5(5.5,6.1)$ & $5.3(5.3,5.9)$ \\
\hline Serum albumin $(g / l)$ & $45.2 \pm 2.3$ & $45.2 \pm 2.3$ & $45.1 \pm 2.2$ \\
\hline Serum DBP $(\mu \mathrm{mol} / \mathrm{l})$ & $3.7 \pm 0.5$ & $3.7 \pm 0.5$ & $3.7 \pm 0.6$ \\
\hline Serum total $25(\mathrm{OH}) \mathrm{D}(\mathrm{nmol} / \mathrm{l})$ & $60.7 \pm 21.6$ & $59.9 \pm 22.0$ & $61.5 \pm 21.1$ \\
\hline Serum calculated free $25(\mathrm{OH}) \mathrm{D}(\mathrm{pmol} / \mathrm{l})$ & $20.4 \pm 7.0$ & $20.4 \pm 7.2$ & $20.4 \pm 6.7$ \\
\hline Serum calculated bio-available $25(\mathrm{OH}) \mathrm{D}$ (nmol/l) & $8.3 \pm 2.8$ & $8.3 \pm 3.0$ & $8.3 \pm 2.6$ \\
\hline Serum directly measured free $25(\mathrm{OH}) \mathrm{D}(\mathrm{pmol} / \mathrm{l})$ & $13.7 \pm 4.2$ & $13.7 \pm 4.3$ & $13.7 \pm 4.2$ \\
\hline
\end{tabular}

PTH, parathyroid hormone; DBP, vitamin D binding protein; 25(OH)D, 25-hydroxyvitamin D. 
Table 2 Distribution of sex, age, BMI, albumin, DBP and vitamin D parameters according to DBP phenotype. General linear model with sex, BMI, age and season as covariates. Bonferroni method for post-hoc analysis.

\begin{tabular}{|c|c|c|c|c|c|c|}
\hline & \multicolumn{6}{|c|}{ DBP phenotypes } \\
\hline & Gc1S/Gc1S & Gc1S/Gc1F & Gc1S/Gc2 & Gc1F/Gc1F & Gc1F/Gc2 & $\mathrm{Gc} 2 / \mathrm{Gc} 2$ \\
\hline Number of subjects & 148 & 124 & 117 & 20 & 39 & 24 \\
\hline Sex (females/males) & $58 / 90$ & $53 / 71$ & $37 / 80$ & $7 / 13$ & $16 / 23$ & $8 / 16$ \\
\hline BMI $\left(\mathrm{kg} / \mathrm{m}^{2}\right)$ & $29.3 \pm 4.5$ & $30.2 \pm 4.2$ & $30.4 \pm 4.2$ & $31.3 \pm 4.0$ & $29.7 \pm 4.6$ & $30.1 \pm 2.9$ \\
\hline Age (years) & $62.2 \pm 8.4$ & $61.3 \pm 9.2$ & $62.4 \pm 8.4$ & $63.3 \pm 8.9$ & $61.3 \pm 9.0$ & $62.4 \pm 9.3$ \\
\hline PTH (pmol/l) & $5.6(5.2,5.9)$ & $6.0(5.5,6.4)$ & $5.9(5.4,6.3)$ & $5.3(4.6,5.9)$ & $5.4(5.0,5.7)$ & $5.2(4.5,5.8)$ \\
\hline Serum albumin $(g / l)$ & $45.1 \pm 2.3$ & $45.3 \pm 2.0$ & $45.1 \pm 2.5$ & $45.5 \pm 2.0$ & $45.4 \pm 2.2$ & $45.4 \pm 2.5$ \\
\hline Serum DBP $(\mu \mathrm{mol} / \mathrm{l})$ & $3.7 \pm 0.5^{\mathrm{b}}$ & $3.8 \pm 0.5^{\mathrm{b}}$ & $3.6 \pm 0.5^{\mathrm{b}}$ & $3.9 \pm 0.7^{b}$ & $3.8 \pm 0.7^{b}$ & $3.1 \pm 0.4^{a}$ \\
\hline Serum total $25(\mathrm{OH}) \mathrm{D}(\mathrm{nmol} / \mathrm{l})$ & $62.9 \pm 23.9^{b}$ & $64.2 \pm 22.9^{b}$ & $59.6 \pm 19.6^{d}$ & $56.8 \pm 17.0$ & $56.9 \pm 17.7$ & $43.9 \pm 13.5^{a}$, \\
\hline Serum calculated free $25(\mathrm{OH}) \mathrm{D}(\mathrm{pmol} / \mathrm{l})$ & $21.0 \pm 7.4$ & $21.1 \pm 6.9$ & $20.4 \pm 6.8$ & $18.6 \pm 6.4$ & $18.8 \pm 6.2$ & $17.3 \pm 5.5$ \\
\hline Serum calculated bio-available $25(\mathrm{OH}) \mathrm{D}(\mathrm{nmol} / \mathrm{l})$ & $8.6 \pm 3.1$ & $8.7 \pm 2.8$ & $8.3 \pm 2.7$ & $7.7 \pm 2.7$ & $7.7 \pm 2.6$ & $7.1 \pm 2.2$ \\
\hline Serum directly measured free $25(\mathrm{OH}) \mathrm{D}(\mathrm{pmol} / \mathrm{l})$ & $13.4 \pm 4.2$ & $14.2 \pm 4.3$ & $13.9 \pm 4.2$ & $12.4 \pm 3.3$ & $14.0 \pm 4.6$ & $12.2 \pm 4.1$ \\
\hline
\end{tabular}

DBP, vitamin D binding protein; 25(OH)D, 25-hydroxyvitamin D.

${ }^{a}$ Significantly lower than $P<0.001$.

${ }^{\mathrm{b}} P<0.001$.

'Significantly lower than $P<0.05$

${ }^{\mathrm{d}} P<0.05$.

Serum total $25(\mathrm{OH}) \mathrm{D}$ concentrations were significantly lower for the phenotype Gc2/Gc2 compared to Gc1S/Gc1S, Gc1S/Gc1F and GC1S/Gc2 (Table 2). The phenotype Gc2/Gc2 also had significantly lower serum DBP concentration compared with all the other phenotype groups (Table 2).

For calculated free $25(\mathrm{OH}) \mathrm{D}$, calculated bio-available $25(\mathrm{OH}) \mathrm{D}$ and directly measured free $25(\mathrm{OH}) \mathrm{D}$ the differences between the DBP phenotypes diminished and were no longer statistically significant (Table 2). The least differences between phenotypes were found for the direct measurements; as an example the difference between Gc2/Gc2 and Gc1S/Gc1S were 30.2\% for total 25(OH)D, $17.6 \%$ for calculated free $25(\mathrm{OH}) \mathrm{D}$ and only $9.0 \%$ for directly measured free $25(\mathrm{OH}) \mathrm{D}$.

We also calculated free $25(\mathrm{OH}) \mathrm{D}$ using specific binding coefficients for the six different DBP phenotypes; however, this did not improve the results (data not shown).

\section{Serum total 25(OH)D, calculated free 25(OH)D, calculated bio-available 25(OH)D, directly measured free 25(OH)D and DBP in relation to sex, BMI, age and season at baseline}

Males had significantly lower serum total 25(OH)D than females, a difference of $10.5 \%$ (Supplementary Table 3, see section on supplementary data given at the end of this article). Similarly, serum DBP concentrations were significantly lower for males compared to females; and in line with this no significant differences were found for serum calculated free $25(\mathrm{OH}) \mathrm{D}$, calculated bio-available $25(\mathrm{OH}) \mathrm{D}$ or directly measured free $25(\mathrm{OH}) \mathrm{D}$ concentrations (Supplementary Table 3).

With increasing BMI a non-significant trend $(P=0.08)$ for decreasing serum total $25(\mathrm{OH}) \mathrm{D}$ was seen with a $9.2 \%$ difference between the lowest and highest BMI groups. A similar, but significant trend was seen for serum DBP. As for total $25(\mathrm{OH}) \mathrm{D}$ there were no significant differences in the free and bio-available $25(\mathrm{OH}) \mathrm{D}$ concentrations between BMI groups; further, for the directly measured free $25(\mathrm{OH}) \mathrm{D}$ the difference had almost completely disappeared (Supplementary Table 3).

There was with increasing age a significant linear trend with increasingly higher serum total $25(\mathrm{OH}) \mathrm{D}$, calculated free $25(\mathrm{OH}) \mathrm{D}$, calculated bio-available $25(\mathrm{OH}) \mathrm{D}$ and directly measured free 25(OH)D (Supplementary Table 3). However, no such trend was seen for serum DBP, and therefore the differences between the lowest and highest age groups for total 25(OH)D and the corresponding differences for directly measured free $25(\mathrm{OH}) \mathrm{D}$ were basically the same (17.0\% and $17.1 \%$ respectively).

For season we compared the three consecutive highest months of serum total 25(OH)D (July-September) with the three lowest (February-April), and since their serum DBP did not differ significantly, the difference remained statistically significant, and also almost identical, for the calculated free $25(\mathrm{OH}) \mathrm{D}$, calculated bio-available $25(\mathrm{OH}) \mathrm{D}$ and directly measured free $25(\mathrm{OH}) \mathrm{D}(P<0.001)$ (data not shown). 
Table 3 Correlations between variables.

\begin{tabular}{|c|c|c|c|c|c|}
\hline & $\begin{array}{l}\text { Serum total } \\
\text { 25(OH)D }(\mathrm{nmol} / \mathrm{l})\end{array}$ & $\begin{array}{l}\text { Serum directly measured } \\
\text { free } 25(\mathrm{OH}) \mathrm{D}(\mathrm{pmol} / \mathrm{l})\end{array}$ & $\begin{array}{c}\text { Serum } \\
\text { DBP }(\mu \mathrm{mol} / \mathrm{l})\end{array}$ & $\begin{array}{c}\text { Serum } \\
\text { albumin }(g / l)\end{array}$ & $\begin{array}{c}\text { Serum } \\
\text { PTH }(p m o l / l)\end{array}$ \\
\hline Serum total $25(\mathrm{OH}) \mathrm{D}(\mathrm{nmol} / \mathrm{l})$ & 1 & $0.73 *$ & $0.24 *$ & -0.04 & $-0.15^{\star}$ \\
\hline $\begin{array}{l}\text { Serum directly measured free } 25(\mathrm{OH}) \mathrm{D} \\
(\mathrm{pmol} / \mathrm{l})\end{array}$ & $0.73 *$ & 1 & 0.05 & -0.05 & $-0.12 *$ \\
\hline Serum DBP $(\mu \mathrm{mol} / \mathrm{l})$ & $0.24 *$ & 0.05 & 1 & $0.15 *$ & -0.04 \\
\hline Serum albumin $(g / l)$ & -0.04 & -0.05 & $0.15 *$ & 1 & $-0.06^{\dagger}$ \\
\hline Serum PTH $(p m o l / l)^{a}$ & $-0.21 *$ & $-0.17^{*}$ & -0.05 & -0.09 & 1 \\
\hline
\end{tabular}

${ }^{*} P<0.001 ;{ }^{\dagger} P<0.05 ; 25(\mathrm{OH}) \mathrm{D}, 25$-hydroxyvitamin $\mathrm{D} ; \mathrm{DBP}$, vitamin $\mathrm{D}$ binding protein; PTH, parathyroid hormone.

anotes log-transformed data.

\section{Correlations for serum total 25(OH)D, calculated free 25(OH)D, directly measured free 25(OH)D, albumin, DBP and PTH at baseline}

Serum PTH was negatively and similarly correlated with serum total 25(OH)D and directly measured free 25(OH)D (Table 3). Additionally, strong correlations were found between serum total $25(\mathrm{OH}) \mathrm{D}$ and directly measured free 25(OH)D (Table 3), and also between all other vitamin D parameters (data not shown). Serum DBP correlated with total $25(\mathrm{OH}) \mathrm{D}$, but not the directly measured free 25(OH)D (Table 3).

\section{Effect of vitamin D supplementation on serum DBP, total 25(OH)D, calculated free 25(OH)D and directly measured free 25(OH)D}

In both the vitamin $\mathrm{D}$ and the placebo group there was a slight and similar non-significant decrease in serum DBP after 1 year $(-0.2 \pm 0.5$ and $-0.2 \pm 0.6 \mu \mathrm{mol} / 1$ respectively). Similarly, there were no statistically significant differences between the six DBP phenotypes, sexes, BMI groups or age groups regarding change in serum DBP (Supplementary Tables 4 and 5, see section on supplementary data given at the end of this article). Further, there were no significant differences between DBP phenotypes, sexes or age groups in changes in serum total $25(\mathrm{OH}) \mathrm{D}$, calculated free $25(\mathrm{OH}) \mathrm{D}$ or directly measured free 25(OH)D (Supplementary Tables 4 and 5). Even so, there appeared to be non-significant differences in the increase in serum total $25(\mathrm{OH}) \mathrm{D}$ between DBP groups phenotype (Supplementary Table 4). For all 25(OH)D measures the highest increases were seen for subjects in the lowest BMI groups (Supplementary Table 5).

There was a strong correlation between increase in all measures of serum $25(\mathrm{OH}) \mathrm{D}$ as exemplified between delta serum total $25(\mathrm{OH}) \mathrm{D}$ and delta serum directly measured free $25(\mathrm{OH}) \mathrm{D}$ in Fig. 1 . The correlation was similar for all six DBP phenotypes (data not shown).

\section{Discussion}

In the present study we have found that serum total 25(OH)D concentrations are dependent on DBP phenotype, that differences between DBP phenotypes diminish when calculating or measuring serum free $25(\mathrm{OH}) \mathrm{D}$, and that serum DBP concentrations are unaffected by vitamin D supplementation. Further, calculations appear to overestimate the free $25(\mathrm{OH}) \mathrm{D}$ concentrations compared to the direct measurements.

Serum total 25(OH)D concentrations were significantly lower for the DBP phenotype Gc2/Gc2 compared to phenotypes with the Gc1S allele as previously reported (20). Although the serum calculated free $25(\mathrm{OH}) \mathrm{D}$,

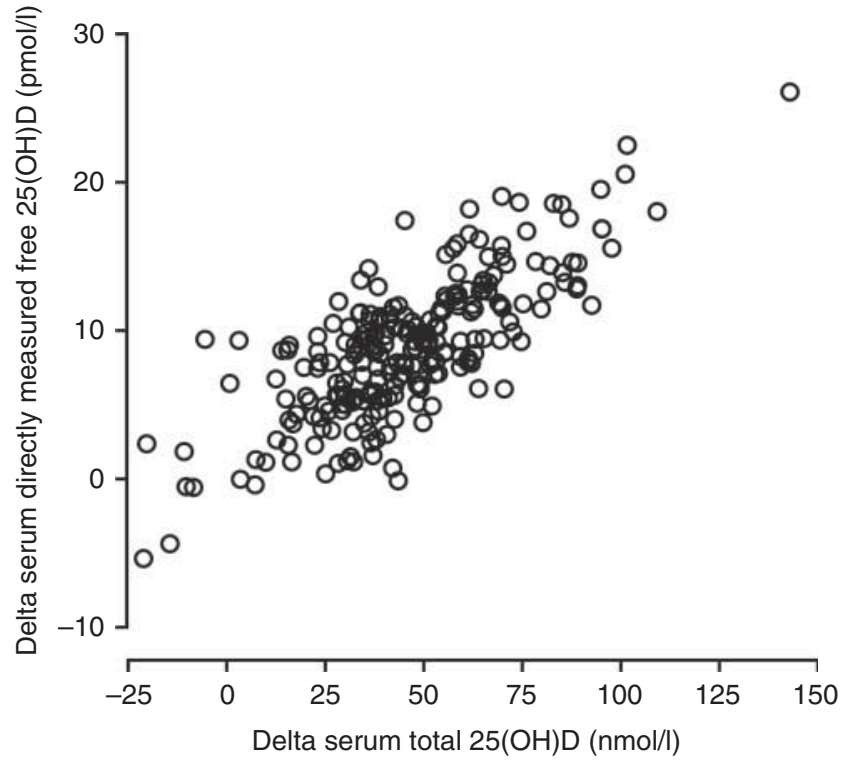

Figure 1

Correlation between delta (12 month values minus baseline value) serum total 25(OH)D and delta directly measured free 25(OH)D. 
calculated bio-available 25(OH)D and directly measured free $25(\mathrm{OH}) \mathrm{D}$ also were lowest in this phenotype, the differences were greatly diminished and no longer significant. Thus, the difference between the DBP phenotypes Gc2/Gc2 and Gc1S/Gc1S decreased from $30.2 \%$ for total $25(\mathrm{OH}) \mathrm{D}$ to $9.0 \%$ for directly measured free $25(\mathrm{OH}) \mathrm{D}$. This is in line with the almost identical free $25(\mathrm{OH}) \mathrm{D}$ concentrations in black and white Americans $(9,11)$, despite great differences in total $25(\mathrm{OH}) \mathrm{D}$, due to different distribution of DBP phenotypes (4). This could also partly explain why African Americans have better bone health than European Americans despite lower total 25(OH)D concentrations.

It is well known that serum DBP concentrations are affected by phenotype (21), and in our study serum DBP concentrations for the phenotype Gc2/Gc2 were significantly lower compared to all other phenotypes. This has also been found in most $(20,22,23)$, but not all previous studies (9). Thus, Powe et al. (9) found that the DBP phenotype Gc1F/Gc1F, predominantly found in black Americans, had by far the lowest serum DBP concentration. This is contrary to our study, and other studies from Scandinavia $(21,22)$, where this phenotype had the highest serum DBP concentration. As reported by Bouillon et al. the discrepancy may be due to differences in antibodies used in the DBP assays (24), or perhaps it reflects that there are other race-related factors than DBP phenotype that affect the serum DBP concentration.

Males had significantly lower serum total 25(OH)D concentrations and also serum DBP concentrations than females. For calculated free $25(\mathrm{OH}) \mathrm{D}$ and calculated bioavailable $25(\mathrm{OH}) \mathrm{D}$ these differences between the sexes diminished, and for the directly measured free $25(\mathrm{OH}) \mathrm{D}$ the concentrations were equal. The difference in serum DBP between sexes has previously been reported (25) and is most likely caused by the estrogen susceptible DBP synthesis (4). Similar, although non-significant, the difference between the lowest and highest BMI group for serum total 25(OH)D concentrations were reduced for the directly measured free $25(\mathrm{OH}) \mathrm{D}$, probably because of the significant linear trend with lower serum DBP concentration with higher BMI. For BMI earlier reports are conflicting with some reporting differences in serum DBP (26), while others report no differences $(25,27)$. This question is therefore not settled.

As in previous reports from our region $(28,29)$, there was for age groups a significant linear trend with the highest serum total $25(\mathrm{OH}) \mathrm{D}$ concentrations in the oldest subjects. This is most likely due to a diet richer in fatty fish and a higher use of vitamin D supplements in the oldest age groups (28). However, serum DBP did not differ between age groups, and a significant positive linear trend was also seen for all the other $25(\mathrm{OH}) \mathrm{D}$ measures.

Similar to that seen for age group, there were no differences in serum DBP between the months with the highest and lowest serum total $25(\mathrm{OH}) \mathrm{D}$ concentrations, and accordingly, the differences between these months remained for serum calculated free $25(\mathrm{OH}) \mathrm{D}$, calculated bioavailable $25(\mathrm{OH}) \mathrm{D}$ and directly measured free $25(\mathrm{OH}) \mathrm{D}$.

We found that the calculated serum free $25(\mathrm{OH}) \mathrm{D}$ concentrations are overestimated compared to the directly measured free $25(\mathrm{OH}) \mathrm{D}$. For calculations of serum free 25(OH)D concentration DBP concentrations are needed. Since different DBP assays recognize the DBP phenotypes differently $(11,24)$, this will affect the calculated free $25(\mathrm{OH}) \mathrm{D}$ concentrations. Furthermore, the validity of the equation for calculating free $25(\mathrm{OH}) \mathrm{D}$ concentration which is derived from an equation for free testosterone (2), has been questioned (24). Therefore, it may be wise not to use the calculated concentrations before these issues have been settled.

We also performed analyses with the DBP phenotype specific binding coefficients. However, and contrary to what we expected, this did not improve the results. The binding coefficients for Gc1S, Gc1F and GC2 are the binding coefficients for the homozygote DBP phenotypes; however, the binding coefficients used for the heterozygote DBP phenotypes were the mean of the two combined haplotypes binding coefficient (30). These binding coefficients may not be correct, which may at least partly explain our unexpected findings.

Since vitamin D both indirectly, through increased calcium absorption from the intestines, and directly, through inhibition of PTH synthesis, decreases the PTH secretion, the serum PTH concentrations has been suggested as a vitamin D biomarker (31). One could therefore hypothesize that the $25(\mathrm{OH}) \mathrm{D}$ measure that best correlate with the serum PTH concentrations would be the best indicator of the vitamin D status. Unfortunately, previous studies are conflicting; Schwartz et al. (32) reported a significant inverse correlation with PTH for directly measured free $25(\mathrm{OH}) \mathrm{D}$, but not for calculated free 25(OH)D, whereas Aloia et al. (11) in one study reported a significant negative correlation with PTH for total $25(\mathrm{OH}) \mathrm{D}$, but not for directly measured free 25(OH)D. However, in another study by Aloia et al. (33) a significantly negative correlation for both total $25(\mathrm{OH}) \mathrm{D}$ and directly measured free $25(\mathrm{OH}) \mathrm{D}$ was found, and in our 
study, all measures of $25(\mathrm{OH}) \mathrm{D}$ had a similar and negative correlation with PTH. Although the free hormone hypothesis is appealing, it should be recalled that there is a receptor-mediated endocytosis of the DBP/total $25(\mathrm{OH}) \mathrm{D}$ complex in the proximal renal cells (34), and probably also in other cells (1), which could favor serum total $25(\mathrm{OH}) \mathrm{D}$ as an indicator of vitamin D status.

As compared to placebo, there was no effect on the serum DBP concentrations by vitamin D supplementation for 1 year regardless of DBP phenotype, sex, BMI or age group which is similar to that reported by Ponda et al. (13) and Sonderman et al. (35). Similarly, in the vitamin D group there were no significant differences in increase for any of the vitamin D parameters between the DBP phenotypes, sexes or age groups. On the other hand, there appear to be non-significant differences between the DBP phenotype groups regarding the increase in serum total $25(\mathrm{OH}) \mathrm{D}$; however, the DBP phenotype groups are small and thereby limits the power to detect any real differences. It therefore appears unlikely that the DBP concentration is regulated in order to keep the free fraction of serum $25(\mathrm{OH}) \mathrm{D}$ stable as seen in other endocrine systems (36).

There are some limitations to our study; we included subjects with prediabetes which limits the generalizability of the results, the study population consists almost exclusively of Caucasians leaving us with a skewed distribution of DBP phenotypes, and we did not have bone density measurements that could have given additional information regarding which $25(\mathrm{OH}) \mathrm{D}$ parameter is the best biomarker of vitamin D status. On the other hand, we included a large number of subjects, had direct measurements of serum free $25(\mathrm{OH}) \mathrm{D}$, and could also examine the effects of vitamin D supplementation on different vitamin D parameters and serum DBP, which so far have not been thoroughly studied.

In conclusion, we have found that the direct measurement of free $25(\mathrm{OH}) \mathrm{D}$ diminishes differences between DBP phenotypes and sexes as compared to serum total 25(OH)D. In situations where DBP phenotypes differ between groups, as seen between white and black Americans, and in conditions associated with low DBP concentrations like liver cirrhosis or nephritic syndrome, or high DBP concentrations like pregnancy and estrogen therapy, direct measurement of serum free $25(\mathrm{OH}) \mathrm{D}$ should be considered.

Supplementary data

This is linked to the online version of the paper at http://dx.doi.org/10.1530/ EJE-15-1089.
Declaration of interest

The authors declare that there is no conflict of interest that could be perceived as prejudicing the impartiality of the research reported.

\section{Funding}

This study was supported by the Novo Nordisk foundation (grant number: R195-A16126), the North Norway Regional Health Authority (grant number: 6856/SFP1029-12), the Norwegian Diabetes Association, UiT The Arctic University of Norway and the Research Council of Norway (grant number: 184766).

\section{Author contribution statement}

$\mathrm{R}$ Jorde is the guarantor of this work and had full access to all the data in the study and takes responsibility for the integrity of the data and the accuracy of the data analysis. S T Sollid researched data and wrote the manuscript; M Y S Hutchinson researched data; all authors contributed to the discussion, review and editing of the manuscript.

\section{Acknowledgements}

We thank the staff at the Clinical Research Unit for superb assistance and the Tromsø Study for providing data necessary for the inclusion of the participants.

\section{References}

1 Chun RF. New perspectives on the vitamin D binding protein. Cell Biochemistry and Function 201230 445-456. (doi:10.1002/cbf.2835)

2 Bikle DD, Gee E, Halloran B, Kowalski MA, Ryzen E \& Haddad JG. Assessment of the free fraction of 25-hydroxyvitamin D in serum and its regulation by albumin and the vitamin D-binding protein. Journal of Clinical Endocrinology and Metabolism 198663 954-959. (doi:10.1210/ jcem-63-4-954)

3 Chun RF, Peercy BE, Orwoll ES, Nielson CM, Adams JS \& Hewison M. Vitamin D and DBP: the free hormone hypothesis revisited.

Journal of Steroid Biochemistry and Molecular Biology 2014144 132-137. (doi:10.1016/j.jsbmb.2013.09.012)

4 Speeckaert M, Huang G, Delanghe JR \& Taes YE. Biological and clinical aspects of the vitamin D binding protein (Gc-globulin) and its polymorphism. Clinica Chimica Acta 2006372 33-42. (doi:10.1016/ j.cca.2006.03.011)

5 Lai JC, Bikle DD, Lizaola B, Hayssen H, Terrault NA \& Schwartz JB. Tota $25(\mathrm{OH})$ vitamin $\mathrm{D}$, free $25(\mathrm{OH})$ vitamin $\mathrm{D}$ and markers of bone turnover in cirrhotics with and without synthetic dysfunction. Liver International 201535 2294-2300. (doi:10.1111/liv.12819)

6 Bouillon R, Van Assche FA, Van Baelen H, Heyns W \& De Moor P. Influence of the vitamin D-binding protein on the serum concentration of 1,25-dihydroxyvitamin D3. Significance of the free 1,25-dihydroxyvitamin D3 concentration. Journal of Clinical Investigation 198167 589-596. (doi:10.1172/JCI110072)

7 Moller UK, Streym S, Jensen LT, Mosekilde L, Schoenmakers I, Nigdikar S \& Rejnmark L. Increased plasma concentrations of vitamin D metabolites and vitamin D binding protein in women using hormonal contraceptives: a cross-sectional study. Nutrients 20135 3470-3480. (doi:10.3390/nu5093470)

8 Braun A, Bichlmaier R \& Cleve H. Molecular analysis of the gene for the human vitamin-D-binding protein (group-specific component): allelic differences of the common genetic GC types. Human Genetics 199289 401-406. (doi:10.1007/BF00194311)

9 Powe CE, Evans MK, Wenger J, Zonderman AB, Berg AH, Nalls M, Tamez H, Zhang D, Bhan I, Karumanchi SA et al. Vitamin D-binding 
protein and vitamin D status of black Americans and white Americans. New England Journal of Medicine 2013369 1991-2000. (doi:10.1056/ NEJMoa1306357)

10 O'Connor MY, Thoreson CK, Ramsey NL, Ricks M \& Sumner AE. The uncertain significance of low vitamin D levels in African descent populations: a review of the bone and cardiometabolic literature. Progress in Cardiovascular Diseases 201356 261-269. (doi:10.1016/ j.pcad.2013.10.015)

11 Aloia J, Mikhail M, Dhaliwal R, Shieh A, Usera G, Stolberg A, Ragolia L \& Islam S. Free 25(OH)D and the vitamin D paradox in African Americans. Journal of Clinical Endocrinology and Metabolism 2015100 3356-3363. (doi:10.1210/JC.2015-2066)

12 Glendenning P, Chew GT, Inderjeeth CA, Taranto M \& Fraser WD. Calculated free and bioavailable vitamin D metabolite concentrations in vitamin D-deficient hip fracture patients after supplementation with cholecalciferol and ergocalciferol. Bone 201356 271-275. (doi:10.1016/ j.bone.2013.06.012)

13 Ponda MP, McGee D \& Breslow JL. Vitamin D-binding protein levels do not influence the effect of vitamin D repletion on serum PTH and calcium: data from a randomized, controlled trial. Journal of Clinical Endocrinology and Metabolism 201499 2494-2499. (doi:10.1210/jc.2014-1181)

14 Sollid ST, Hutchinson MY, Fuskevag OM, Figenschau Y, Joakimsen RM, Schirmer H, Njolstad I, Svartberg J, Kamycheva E \& Jorde R. No effect of high-dose vitamin D supplementation on glycemic status or cardiovascular risk factors in subjects with prediabetes. Diabetes Care 201437 2123-2131. (doi:10.2337/dc14-0218)

15 Hutchinson MS, Grimnes G, Joakimsen RM, Figenschau Y \& Jorde R. Low serum 25-hydroxyvitamin D levels are associated with increased all-cause mortality risk in a general population: the Tromso study. European Journal of Endocrinology/European Federation of Endocrine Societies 2010162 935-942. (doi:10.1530/EJE-09-1041)

16 Maunsell Z, Wright DJ \& Rainbow SJ. Routine isotope-dilution liquid chromatography-tandem mass spectrometry assay for simultaneous measurement of the 25-hydroxy metabolites of vitamins D2 and D3. Clinical Chemistry 200551 1683-1690. (doi:10.1373/clinchem.2005. 052936)

17 Kauppinen-Makelin R, Tahtela R, Loyttyniemi E, Karkkainen J \& Valimaki MJ. A high prevalence of hypovitaminosis D in Finnish medical in- and outpatients. Journal of Internal Medicine 2001249 559-563. (doi:10.1046/j.1365-2796.2001.00847.x)

18 Vermeulen A, Verdonck L \& Kaufman JM. A critical evaluation of simple methods for the estimation of free testosterone in serum. Journal of Clinical Endocrinology and Metabolism 199984 3666-3672. (doi:10.1210/jcem.84.10.6079)

19 Powe CE, Ricciardi C, Berg AH, Erdenesanaa D, Collerone G, Ankers E, Wenger J, Karumanchi SA, Thadhani R \& Bhan I. Vitamin D-binding protein modifies the vitamin D-bone mineral density relationship. Journal of Bone and Mineral Research 201126 1609-1616. (doi:10.1002/ jbmr.387)

20 Lauridsen AL, Vestergaard P, Hermann AP, Brot C, Heickendorff L, Mosekilde L \& Nexo E. Plasma concentrations of 25-hydroxy-vitamin D and 1,25-dihydroxy-vitamin D are related to the phenotype of Gc (vitamin D-binding protein): a cross-sectional study on 595 early postmenopausal women. Calcified Tissue International 200577 15-22. (doi:10.1007/s00223-004-0227-5)

21 Lauridsen AL, Vestergaard P \& Nexo E. Mean serum concentration of vitamin D-binding protein (Gc globulin) is related to the Gc phenotype in women. Clinical Chemistry 200147 753-756. (doi:10.1007/s00223004-0227-5)
22 Johnsen MS, Grimnes G, Figenschau Y, Torjesen PA, Almas B \& Jorde R. Serum free and bio-available 25-hydroxyvitamin D correlate better with bone density than serum total 25-hydroxyvitamin D. Scandinavian Journal of Clinical and Laboratory Investigation 201474 177-183. (doi:10.3109/00365513.2013.869701)

23 Taes YE, Goemaere S, Huang G, Van Pottelbergh I, De Bacquer D, Verhasselt B, Van den Broeke C, Delanghe JR \& Kaufman JM. Vitamin D binding protein, bone status and body composition in communitydwelling elderly men. Bone 200638 701-707. (doi:10.1016/j.bone. 2005.10.006)

24 Powe CE, Karumanchi SA \& Thadhani R. Vitamin D-binding protein and vitamin D in blacks and whites. New England Journal of Medicine 2014370 880-881. (doi:10.1056/NEJMc1315850)

25 Bolland MJ, Grey AB, Ames RW, Horne AM, Mason BH, Wattie DJ, Gamble GD, Bouillon R \& Reid IR. Age-, gender-, and weight-related effects on levels of 25-hydroxyvitamin D are not mediated by vitamin D binding protein. Clinical Endocrinology 200767 259-264. (doi:10.1111/ j.1365-2265.2007.02873.x)

26 Karlsson T, Osmancevic A, Jansson N, Hulthen L, Holmang A \& Larsson I. Increased vitamin D-binding protein and decreased free $25(\mathrm{OH}) \mathrm{D}$ in obese women of reproductive age. European Journal of Nutrition 201453 259-267. (doi:10.1007/s00394-013-0524-8)

27 Winters SJ, Chennubhatla R, Wang C \& Miller JJ. Influence of obesity on vitamin D-binding protein and 25-hydroxy vitamin D levels in African American and white women. Metabolism: Clinical and Experimental 200958 438-442. (doi:10.1016/j.metabol.2008.10.017)

28 Jorde R, Figenschau Y, Emaus N, Hutchinson M \& Grimnes G. Serum 25-hydroxyvitamin D levels are strongly related to systolic blood pressure but do not predict future hypertension. Hypertension $2010 \mathbf{5 5}$ 792-798. (doi:10.1161/HYPERTENSIONAHA.109.143990)

29 Sollid ST, Hutchinson MY, Fuskevag OM, Joakimsen RM \& Jorde R. Large individual differences in serum 25-hydroxyvitamin $\mathrm{D}$ response to vitamin D supplementation: effects of genetic factors, body mass index, and baseline concentration. Results from a randomized controlled trial. Hormone and Metabolic Research, 2015. In press. (doi:10.1055/s-0034-1398617)

30 Arnaud J \& Constans J. Affinity differences for vitamin D metabolites associated with the genetic isoforms of the human serum carrier protein (DBP). Human Genetics 199392 183-188. (doi:10.1007/BF00219689)

31 Seamans KM \& Cashman KD. Existing and potentially novel functional markers of vitamin D status: a systematic review. American Journal of Clinical Nutrition 200989 1997s-2008s. (doi:10.3945/ajcn.2009.27230D)

32 Schwartz JB, Lai J, Lizaola B, Kane L, Markova S, Weyland P, Terrault NA, Stotland N \& Bikle D. A comparison of measured and calculated free $25(\mathrm{OH})$ vitamin D levels in clinical populations. Journal of Clinical Endocrinology and Metabolism 201499 1631-1637. (doi:10.1210/jc.2013-3874)

33 Aloia J, Dhaliwal R, Mikhail M, Shieh A, Stolberg A, Ragolia L, Fazzari M \& Abrams SA. Free 25(OH)D and calcium absorption, PTH and markers of bone turnover. Journal of Clinical Endocrinology and Metabolism 2015 100 4140-4145. (doi:10.1210/jc.2015-2548)

34 Nykjaer A, Dragun D, Walther D, Vorum H, Jacobsen C, Herz J, Melsen F, Christensen EI \& Willnow TE. An endocytic pathway essential for renal uptake and activation of the steroid $25-(\mathrm{OH})$ vitamin D3. Cell 199996 507-515. (doi:10.1016/S0092-8674(00)80655-8)

35 Sonderman JS, Munro HM, Blot WJ \& Signorello LB. Reproducibility of serum 25-hydroxyvitamin d and vitamin D-binding protein levels over time in a prospective cohort study of black and white adults. American Journal of Epidemiology 2012176 615-621. (doi:10.1093/aje/kws141)

36 Ekins R. The free hormone hypothesis and measurement of free hormones. Clinical Chemistry 199238 1289-1293.
Received 5 November 2015

Revised version received 7 December 2015

Accepted 5 January 2016 